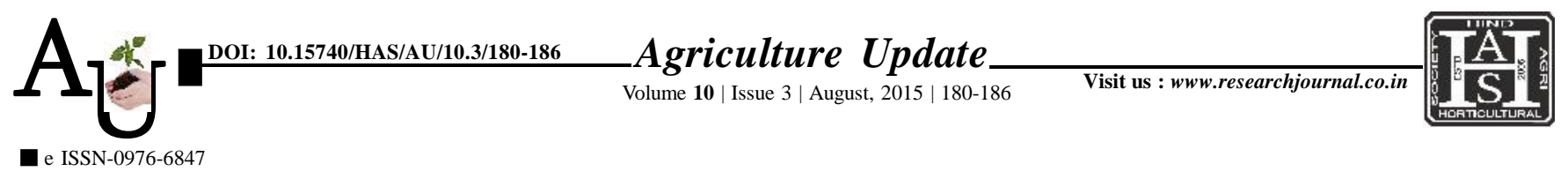

\title{
Research article: Decomposition analysis of cotton in Amravati division
}

\section{P.S. PARDHI, S.M. SARAP, S.N. INGLE AND K.R. MANKAWADE}

Article Chronicle: Received :

27.06.2015;

Revised :

01.07.2015;

Accepted :

02.08 .2015

\section{Key Words :}

Compound growth rates, Co-efficient of variation, Instability, Production,

Productivity
SUMMARY : In this study, an attempt has been made to study the growth and instability of cotton crop in Amravati division. The study was based on secondary data on area, production and productivity of cotton crop collected from various government publications. The study revealed that compound growth rate of area under cotton was recorded high during period I. The growth rate of yield under cotton was recorded high during period III. The co-efficient of variation and Coppock's instability index with regards to area (5.41 and $6.35 \%$ ) was lowest in Akola district among cotton growing districts of Amravati division. However, co-efficient of variation with regards to productivity (31.58 \%) was lowest in Yavatmal district and Coppock's instability index with regards to productivity (27.40\%) was lowest in Amravati district. At overall period, the area effect was most stronger factor for increasing production of cotton in all the districts and division as a whole.

How to cite this article : Pardhi, P.S., Sarap, S.M., Ingle, S.N. and Mankawade, K.R. (2015). Decomposition analysis of cotton in Amravati division. Agric. Update, 10(3): 180-186.

\section{Author for correspondence :}

\section{S.M. SARAP}

Department of Agricultural Economics and Statistics, Shri Shivaji Agriculture College, AMRAVATI (M.S.) INDIA

Email: sulbha1233@

gmail.com

See end of the article for authors' affiliations 